\title{
Pengaruh Salinitas dan Aplikasi Bakteri Rhizosfer Toleran Salin Terhadap Komponen Hasil Tanaman Mentimun
}

\author{
Rikza Alfya Anugrah Cahyaty ${ }^{1)}$, Nurul Aini ${ }^{2)}$, Titin Sumarni ${ }^{2)}$ \\ 1) Postgraduate Program, Faculty of Agriculture, Brawijaya University, Jl. Veteran, Malang 65145, Indonesia \\ ${ }^{2)}$ Department of Agronomy, Faculty of Agriculture, Brawijaya University, Jl. Veteran, Malang 65145, Indonesia \\ ${ }^{1)}$ corresponding author: rikzaaac@gmail.com
}

\begin{abstract}
ABSTRAK
Di Indonesia, lahan salin yang potensial untuk dijadikan lahan pertanian sekitar 9,5 juta hektar. Namun, kendala yang dihadapi pada lahan salin membutuhkan teknologi khusus untuk dapat mengurangi efek salinitas pada tanaman. Salah satu teknologi tersebut adalah penggunaan bakteri rhizosfer. Penelitian ini bertujuan untuk mengetahui konsentrasi optimum aplikasi bakteri rhizosfer untuk meningkatkan ketahanan tanaman terhadap salinitas. Isolat bakteri yang digunakan dalam percobaan ini merupakan isolat hasil eksplorasi yang telah diidentifikasi yaitu Bacillus megaterium yang telah terbukti dari hasil percobaan pendahuluan yaitu mampu menambat nitrogen dan penghasil hormon IAA. Percobaan menggunakan rancangan acak kelompok kombinasi yaitu tanah non salin dan tanah salin dengan konsentrasi bakteri tanpa aplikasi bakteri, 7,5 ml L $\mathrm{m}^{-1}$ bakteri rhizosfer, $15 \mathrm{ml} \mathrm{L}^{-1}$ bakteri rhizosfer, 22,5 $\mathrm{ml} \mathrm{L}^{-1}$ bakteri rhizosfer, dan 30 $\mathrm{ml} \mathrm{L}^{-1}$ bakteri rhizosfer. Parameter pengamatan yang dilakukan adalah jumlah bunga jantan, betina, fruit set, bobot buah per buah, diameter dan panjang buah. Hasil penelitian menunjukkan bahwa salinitas menyebabkan tanaman mentimun tidak dapat menghasilkan bunga betina. Aplikasi bakteri rhizosfer dengan konsentrasi $22,5 \mathrm{ml} \mathrm{L}^{-1}$ mampu meningkatkan bobot buah per buah sebesar $20,8 \%$ dibandingkan dengan aplikasi bakteri dengan konsentrasi $7,5 \mathrm{ml} \mathrm{L}^{-1}$.
\end{abstract}

Kata Kunci : Bacillus megaterium, Rhizosfer, Salinitas, Produktivitas

\section{ABSTRACT}

In Indonesia a potential saline area for 9.5 million hectares of agricultural land. However, it can reduce the salinity effect on the plant, one is the use of rhizosphere bacteria. This study aims to determine the optimum concentration of application of rhizosphere bacteria to increase plant resistance to salinity. The bacterial isolates used in this experiment were Bacillus megaterium-strengthened exploratory isolates that had proven to be the result of a preliminary experiment that was capable of inhibiting nitrogen and IAAproducing hormones. The experiment used a combination of randomized groups, with a concentration of 7.5 $\mathrm{ml}$ of $\mathrm{L}-1,15 \mathrm{~mL} \mathrm{~L}^{-1}, 22.5 \mathrm{ml} \mathrm{L}^{-1}$, and $30 \mathrm{ml} \mathrm{L}^{-1}$. Observation parameters were number of male, female, fruit set, fruit weight per fruit, diameter and fruit panjangg. The results showed that the salinity of cucumber plants can not produce female flowers. Application of rhizosphere bacteria with concentration $22.5 \mathrm{ml}$ L-1 able to increase fruit weight per fruit equal to $20.8 \%$ compared with application of bacteria with concentration of $7.5 \mathrm{ml} \mathrm{L}^{-1}$.

Keyword : Bacillus megaterium, Rhizosfer, Salinity, Productivity

\section{PENDAHULUAN}

Salinitas adalah konsentrasi terlarut dalam jumlah besar mempengaruhi pertumbuhan

garam-garam yang dapat kebanyakan tanaman. Kondisi salin menjadi salah satu masalah yang sering dihadapi dalam pembangunan pertanian di Indonesia. Dalam dekade terakhir, beberapa penelitian telah menunjukkan dengan respon adaptif pada tanaman yang dibudidayakan pada tingkatkan konsentrasi garam, dengan berfokus pada kerugian total hasil buah [1] dan perubahan kualitas buah. Bahkan, salinitas mempengaruhi hampir setiap aspek pertumbuhan tanaman fisiologi dan biokimia. Pada setiap fase 
pertumbuhan tanaman tomat memiliki ketahanan yang berbeda terhadap salinitas yang berpengaruh terhadap pertumbuhan. Mentimun termasuk dalam kategori tanaman yang moderat toleran terhadap salinitas, oleh karena itu dibutuhkan teknologi khusus untuk meningkatkan ketahanan tanaman mentimun terhadap cekaman salinitas, salah satunya pemanfaatan PGPR. PGPR adalah bakteri pengoloni akar yang memberikan efek menguntungkan terhadap pertumbuhan tanaman. Pada beberapa penelitian, PGPR telah diteliti mampu memacu pertumbuhan tanaman dan menginduksi ketahanan tanaman sehingga dapat mencegah serangan pathogen [2]. Hingga saat ini penggunaan PGPR di Indonesia sebagai biostimulan dan biofertilizer untuk meningkatkan produksi pertanian masih sangat sedikit, walaupun PGPR berpotensi sangat besar dalam meningkatkan produksi pertanian terutama pada lahan salin [3].

\section{METODE PENELITIAN}

\section{Isolat Bakteri (Pendahuluan)}

Isolat bakteri yang digunakan merupakan bakteri hasil eksplorasi dari tanah salin yang telah di uji mampu menambat nitrogen bebas dan mampu mensintesis hormon IAA. Hasil identifikasi molekuler pada bakteri tersebut diketahui bakteri Bacillus megaterium.

\section{Percobaan rumah kaca}

Percobaan dilakukan pada bulan April-Juni 2017 di rumah kaca Kebun Percobaan Universitas Brawijaya, Desa Jatikerto, Kecamatan Kromengan, Kabupaten Malang, dengan menggunakan rancangan acak kelompok (RAK) yang terdiri dari 10 kombinasi perlakuan yang diulang sebanyak 3 kali. Adapun perlakuan percobaan yaitu SB0: Tanah Non-Salin, $0 \mathrm{ml} \mathrm{L}^{-}$ ${ }^{1}$ air, SB1 : Tanah Non-Salin, 7,5 $\mathrm{ml} \mathrm{L}^{-1}$ air, SB2 : Tanah Non-Salin, $15 \mathrm{ml} \mathrm{L}^{-1}$ air, SB3 : Tanah Non-Salin, $22,5 \mathrm{ml} \mathrm{L}^{-1}$ air, SB4 : Tanah NonSalin, $30 \mathrm{ml} \mathrm{L}^{-1}$ air, SB5 : Tanah Salin, $0 \mathrm{ml} \mathrm{L}^{-1}$ air, SB6 : Tanah Salin, 7,5 $\mathrm{ml} \mathrm{L}^{-1}$ air, SB7 : Tanah Salin, $15 \mathrm{ml} \mathrm{L}^{-1}$ air, SB8 : Tanah Salin, $22,5 \mathrm{ml} \mathrm{L}^{-1}$ air, SB9 : Tanah Salin, $30 \mathrm{ml} \mathrm{L}^{-1}$ air.
Tahapan persiapan media tanam yaitu dengan mencampurkan $9 \mathrm{~kg}$ tanah dan $1 \mathrm{~kg}$ pupuk kandang. Setelah itu media dicampur dan di sterilisasi dengan menyemprotkan formalin $4 \%$ pada media tanam. Simulasi tanah salin dilakukan dengan cara penyiraman larutan $\mathrm{NaCl}$ $5000 \mathrm{ppm}$ atau hingga media mencapai EC antara 5,6 - $5.8 \mathrm{dS} \mathrm{m}^{-1}$ pada media tanam untuk memperoleh kondisi yang hampir sama dengan kawasan salin tingkat sedang. Pengaplikasian (inokulasi) bakteri pada tanaman mentimun dilakukan sebnyaka 4 kali yaitu pada saat penanaman, 7, 14 dan 21 hst. Hasil pengamatan pada penelitia dilakukan uji analisa ragam (uji F) pada taraf 5\% dan 1\%. Apabila terdapat hasil berbeda nyata akan dilanjutkan dengan uji BNT pada taraf $5 \%$.

\section{HASIL DAN PEMBAHASAN}

Pada Tabel 1 menunjukkan pemberian konsentrasi bakteri rhizosfer pada tanah non salin tidak berpengaruh tehadap parameter jumlah bunga jantan. Namun pada tanah salin aplikasi bakteri rhizosref dapat meningkatkan jumlah bunga jantan pada tanaman. Aplikasi bakteri rhizosfer dengan konsentrasi $15 \mathrm{ml} \mathrm{L}^{-1}$ mampu meningkatkan jumlah bunga jantan sebesar 52,2\% jika dibandingkan dengan perlakuan tanah salin tanpa Perlakuan salinitas mampu menurunkan jumlah bunga betina pada tanaman mentimun. Aplikasi bakteri pada tanah non salin memiliki rata-rata jumlah bunga betina yang tidak berbeda nyata.Sedangkan aplikasi bakteri rhizosfer pada tanah salin mampu menunjukkan peningkatan jumlah bunga betina pada tanaman mentimun. Pada perlakuan tanah salin dengan aplikasi bakteri rhizosfer dengan konsentrasi $22,5 \mathrm{ml} \mathrm{L}^{-1}$ mampu meningkatkan jumlah bunga betina $32,2 \%$ jika dibandingkan dengan perlakuan tanah salin dengan konsnetrasi bakteri $7,5 \mathrm{ml} \mathrm{L}^{-1}$. Pembentukan bunga pada tanaman dapat terpengaruh oleh induksi salinitas yang berakibat terhadap gangguan nutrisi, efek osmotik dan ion spesifik [4]. 
Tabel 1. Rata-rata Jumlah Bunga Betina dan Fruit set hasil transformasi Hasil Perlakuan Bakteri Rhizosfer pada Tanah Non-Salin dan Tanah Salin

\begin{tabular}{|c|c|c|c|}
\hline Perlakuan & Bunga Jantan & Bunga Betina & Fruit set $(\%)$ \\
\hline Tanah Non-Salin, $0 \mathrm{ml} \mathrm{L}^{-1}$ & $24,11 \mathrm{~d}$ & $6,89(2,72) d$ & $79,88(2,45) \mathrm{e}$ \\
\hline Tanah Non-Salin, 7,5 $\mathrm{ml} \mathrm{L}^{-1}$ & $24,22 \mathrm{~d}$ & $7,67(2,85) \mathrm{d}$ & $74,42(2,48) \mathrm{e}$ \\
\hline Tanah Non-Salin, $15 \mathrm{ml} \mathrm{L}^{-1}$ & $24,44 \mathrm{~d}$ & $7,56(2,84) \mathrm{d}$ & $71,74(2,41) \mathrm{e}$ \\
\hline Tanah Non-Salin, $22,5 \mathrm{ml} \mathrm{L}^{-1}$ & $26,56 \mathrm{~d}$ & $7,89(2,89) \mathrm{d}$ & $68,14(2,41) \mathrm{e}$ \\
\hline Tanah Non-Salin, $30 \mathrm{ml} \mathrm{L}^{-1}$ & $27,00 \mathrm{~d}$ & $7,78(2,87) \mathrm{d}$ & $74,68(2,48) \mathrm{e}$ \\
\hline Tanah Salin, $0 \mathrm{ml} \mathrm{L}{ }^{-1}$ & $4,78 \mathrm{a}$ & $0,00(0,71)$ a & $0,00(0,71) \mathrm{a}$ \\
\hline Tanah Salin, $7.5 \mathrm{ml} \mathrm{L}^{-1}$ & $7,67 \mathrm{ab}$ & $2,56(1,75) b$ & $66,02(1,47) b$ \\
\hline Tanah Salin, $15 \mathrm{ml} \mathrm{L}^{-1}$ & $10,00 \mathrm{~b}$ & $3,44(1,98) \mathrm{c}$ & $67,65(1,68) \mathrm{c}$ \\
\hline Tanah Salin, 22,5 $\mathrm{ml} \mathrm{L}^{-1}$ & $12,22 \mathrm{bc}$ & $3,78(2,07) \mathrm{c}$ & $66,67(1,73) \mathrm{c}$ \\
\hline Tanah Salin, $30 \mathrm{ml} \mathrm{L}^{-1}$ & $15,00 \mathrm{c}$ & $4,78(2,30) \mathrm{d}$ & $69,95(1,96) d$ \\
\hline BNT 5\% & $* *$ & $* *$ & $* *$ \\
\hline KK & 10,83 & 5,20 & 4,65 \\
\hline
\end{tabular}

Keterangan : hst= Hari Setelah Tanam, BNT $=$ Beda Nyata Terkecil, KK $=$ Koefisien Keragaman. Bilangan yang berada di dalam kurung dan diikuti oleh huruf yang sama, pada kolom umur pengamatan yang sama tidak berbeda nyata berdasarkan uji BNT 5\%.Angka yang berada di dalam kurung merupakan angka hasil transformasi.

Secara umum perlakuan salinitas menyebabkan penurunan bobot buah per buah. Namun dengan aplikasi bakteri rhizosfer mampu membantu tanaman dalam meningkatkan hasil produksi. Hasil penelitian yang ditunjukkan pada Tabel 2, pengamatan pada perlakuan tanah non salin tanpa aplikasi bakteri rhizosfer dan aplikasi bakteri konsentrasi $22,5 \mathrm{ml} \mathrm{L}^{-1}$ mampu meningkatkan bobot buah per buah sebesar 20,8\% jika dibandingkan dengan perlakuan tanah salin tanpa aplikasi bakteri. Aplikasi bakteri rhizosfer juga menunjukkan respon yang sama pada tanah salin yaitu mampu meningkatkan bobot buah per buah. Aplikasi bakteri rhizosfer dengan konsentrasi 22,5 $\mathrm{ml} \mathrm{L}^{-1}$ mampu meningkatkan bobot buah per buah sebesar 20,8\% dibandingkan dengan aplikasi bakteri dengan konsentrasi $7,5 \mathrm{ml} \mathrm{L}^{-1}$. Dan aplikasi bakteri rhizosfer dengan konsentrasi 30

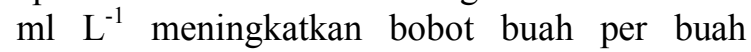
mencapai $26 \%$ dibandingkan dengan konsentrasi bakteri $22,5 \mathrm{ml} \mathrm{L}^{-1}$.

Data yang disajikan pada Tabel 2 menunjukan nilai rata-rata diameter buah
mentimun.P ada pengamatan diameter buah aplikasi bakteri rhizosfer dengan beberapa konsentrasi menunjukkan hasil yang berbeda nyata.Semakin tinggi konsentrasi bakteri rhizosfer yang di aplikasikan pada tanah non salin dan tanah salin semakin meningkatkan diameter buah. Pengamatan pada tanah non salin dengan aplikasi bakteri rhizosfer $30 \mathrm{ml} \mathrm{L}^{-1}$ dapat meningkatkan diameter buah sebesar $7,7 \%$ dibandingkan dengan perlakuan tanah non salin tanpa aplikasi bakteri rhizosfer. Perlakuan tanah non salin aplikasi bakteri 7,5, 15 dan 22,5 memiliki rata-rata diameter buah yang tidak berbeda nyata dengan perlakuan tanah non salin aplikasi bakteri $30 \mathrm{ml} \mathrm{L}^{-1}$.Pada perlakuan tanah salin dengan aplikasi bakteri rhizosfer dengan konsentrasi $15 \mathrm{ml} \mathrm{L}^{-1}$ mampu meningkatkan panjang buah sebesar 12,9\% jika dibandingkan dengan perlakuan tanah salin dengan konsentrasi bakteri $7,5 \mathrm{ml} \mathrm{L}^{-1}$. Pada pelakuan tanah salin dengan aplikasi bekteri rhizofer konsentrasi 30 $\mathrm{ml} \mathrm{L} \mathrm{L}^{-1}$ dapat meningkatkan panjang buah mecapai 10,3\% dibandingkan dengan aplikasi bakteri pada konsentrasi $15 \mathrm{ml} \mathrm{L}^{-1}$. 
Tabel 2. Rata-rata Jumlah Buah per Tanaman, Bobot Buah per Buah dan Bobot Buah Per Tanaman Hasil Perlakuan Bakteri Rhizosfer pada Tanah Non-Salin dan Tanah Salin

\begin{tabular}{|c|c|c|c|}
\hline Perlakuan & $\begin{array}{l}\text { Bobot Buah } \\
\text { per Buah (g) }\end{array}$ & Panjang Buah (cm) & Diameter Buah (cm) \\
\hline Tanah Non-Salin, $0 \mathrm{ml} \mathrm{L}{ }^{-1}$ & $189,44(13,8) \mathrm{e}$ & $20,44(4,58) \mathrm{e}$ & $3,81(2,08) \mathrm{e}$ \\
\hline Tanah Non-Salin, 7,5 $\mathrm{ml} \mathrm{L}^{-1}$ & $187,19(13,7) \mathrm{e}$ & $20,78(4,61) \mathrm{e}$ & $3,94(2,11)$ ef \\
\hline Tanah Non-Salin, $15 \mathrm{ml} \mathrm{L}^{-1}$ & $205,76(14,3) \mathrm{ef}$ & $20,89(4,62) \mathrm{e}$ & $3,97(2,11)$ ef \\
\hline Tanah Non-Salin, $22,5 \mathrm{ml} \mathrm{L}^{-1}$ & $223,12(14,9) \mathrm{f}$ & $20,22(4,55) \mathrm{e}$ & $3,95(2,11)$ ef \\
\hline Tanah Non-Salin, $30 \mathrm{ml} \mathrm{L}^{-1}$ & $221,98(14,9) \mathrm{f}$ & $21,33(4,67) \mathrm{e}$ & $4,13(2,15) \mathrm{f}$ \\
\hline Tanah Salin, $0 \mathrm{ml} \mathrm{L}{ }^{-1}$ & $0,00(0,71) \mathrm{a}$ & $0,00(0,71) \mathrm{a}$ & $0,00(0,71) \mathrm{a}$ \\
\hline Tanah Salin, 7,5 $\mathrm{ml} \mathrm{L}^{-1}$ & $90,82(9,55) b$ & $12,33(3,58) b$ & $2,42(1,71) b$ \\
\hline Tanah Salin, $15 \mathrm{ml} \mathrm{L}^{-1}$ & $101,91(10,1) b$ & $14,67(3,89) \mathrm{c}$ & $2,78(1,81) \mathrm{c}$ \\
\hline Tanah Salin, 22,5 $\mathrm{ml} \mathrm{L}^{-1}$ & $114,75(10,7) \mathrm{c}$ & $16,32(4,10) d$ & $3,02(1,87) \mathrm{cd}$ \\
\hline Tanah Salin, $30 \mathrm{ml} \mathrm{L}^{-1}$ & $155,1(12,4) \mathrm{d}$ & $17,17(4,20) \mathrm{d}$ & $3,10(1,90) \mathrm{d}$ \\
\hline BNT 5\% & $* *$ & $* *$ & $* *$ \\
\hline KK & 4,56 & 5,07 & 5,33 \\
\hline
\end{tabular}

Keterangan : hst= Hari Setelah Tanam, BNT = Beda Nyata Terkecil, KK = Koefisien Keragaman. Bilangan yang berada di dalam kurung dan diikuti oleh huruf yang sama, pada kolom umur pengamatan yang sama tidak berbeda nyata berdasarkan uji BNT 5\%.Angka yang berada di dalam kurung merupakan angka hasil transformasi.

Tanaman yang hidup di lahan salin menghadapi masalah utama, yaitu dalam hal memperoleh air tanah yang potensial airnya lebih negatif [5]. Potensial air tanah yang lebih negatif akan memacu air keluar dari jaringan sehingga tumbuhan kehilangan tekanan turgor. Hal ini menyebabkan penurunan penyerapan air yang dapat menyebabkan tanaman mengalami cekaman air. Selain itu, tanaman pada tanah salin mengalami penurunan dalam penyerapan unsur hara [6]. Salah satu upaya yang dapat dilakukan dalam meningkatkan pertumbuhan dan hasil tanaman pada tanah salin adalah dengan memberikan PGPR sebagai pupuk hayati. [7] melaporkan bahwa perlakuan kombinasi inokulasi bakteri dapat meningkatkan serapan $\mathrm{P}$ and $\mathrm{N}$ secara signifikan dan mengurangi akumulasi $\mathrm{Na}^{+}$pada tanaman dalam kondisi salin. [8] menyatakan bahwa pengaruh salinitas dapat terdeteksi pada parameter panjang tunas, berat basah dan berat kering serta terhambatnya pembentukan buah pada tanaman. cekaman salinitas engakibatkan tanaman kekurangan unsur hara (N P dan $\mathrm{K}$ ) yang merupakan unsur penting dalam perkembangan tanaman. salah satu unsur yang mempengaruhi hasil produksi tanaman adalah unsur P. [9] mengemukakan peranan $\mathrm{P}$ antara lain penting untuk pertumbuhan sel, pembentukan akar halus dan rambut akar, pembentukan bunga, buah, dan biji.

Aplikasi bakteri rhizosfer mampu meningkatkan produksi mentimun pada kondisi salin.Pada dasarnya, tinggi rendahnya komponen hasil suatu tanaman dipengaruhi oleh pertumbuhan organ vegetatifnya [10]. Pada kondisi salin dengan aplikasi bakteri rhizosfer terbukti mampu meningkatkan jumlah daun dan luas daun tanama mentimun.Daun merupakan organ vegetatifpenghasil asilmilat. Sehingga, semakin tinggi jumlah daun dan luas daun makan akan semakin tinggi laju fotosintesis dan asimilat yang dihasilkan akan semakin tinggi. Asimilat yang dihasilkan tersebut akan ditranslokasikan pada organ tanaman salah satunya adalah untuk pembentukan buah. Demikian juga [11], [12] melaporkan bahwa inokulasi PGPR meningkatkan pertumbuhan dan hasil gandum pada kondisi tanah salin. [13] melaporkan adanya peningkatan hasil dari chickpea yang ditanam pada media dengan 
perlakuan $\mathrm{NaCl}(1,8 \%)$ dan menggunakan isolat bakteri pelarut fosfat yaitu Pseudomonas putida.

\section{KESIMPULAN}

Salinitas menyebabkan tanaman mentimun tidak mampu berproduksi, namun aplikasi bakteri rhizosfer $30 \quad \mathrm{ml} \quad \mathrm{L}^{-1}$ mampu meningkatkan produktifitas mentimun. Aplikasi bakteri rhizosfer dengan konsentrasi $22,5 \mathrm{ml} \mathrm{L}^{-1}$ mampu meningkatkan jumlah bunga betina $32,2 \%$ jika dibandingkan dengan perlakuan tanah salin dengan konsnetrasi bakteri $7,5 \mathrm{ml}$ $\mathrm{L}^{-1}$. Aplikasi bakteri rhizosfer dengan konsentrasi $30 \mathrm{ml} \mathrm{L}^{-1}$ meningkatkan bobot buah per buah mencapai $26 \%$ dibandingkan dengan konsentrasi bakteri $22,5 \mathrm{ml} \mathrm{L}^{-1}$. Konsentrasi bakteri rhizosfer yang efektif pada lahan salin adalah $30 \quad \mathrm{ml} \mathrm{L}^{-1}$ yang mampu terus meningkatkan hasil produksi mentimun.

\section{DAFTAR PUSTAKA}

[1] Wan SQ, Kang YH, Wang D, Liu SP, Feng LP 2007 Effect of Drip Irrigation with Saline Water on Tomato (lycopersicon esculentum Mill) Yield and Water Use in Semi-humid Area. Agric Water Manage (90):63-74.

[2] Marwoso E. 2005. Pemanfaatan Rizobakteria untuk Pengendalian Virus Daun Kecil Kacang Panjang (Cowpea little leaft virus). Skripsi. Bogor: Institut Pertanian Bogor.

[3] Khalimi K \& Wirya G. 2009. Pemanfaatan Plant Growth Promoting Rhizobacteria untuk Biostimulasi dan Bioprospecting. Ecotrophic4(2): 131-135.

[4] Pessarakli, M. 1993. Handbook of Plant and Crop Stress.Marcel Dekker Inc. New York. 1180 pp.

[5] Djukri. 2009. Cekaman Salinitas terhadap Pertumbuhan Tanaman. Prosiding Seminar Nasional Penelitian, Pendidikan dan Penerapan MIPA,Fakultas MIPA, Universitas Negeri Yogyakarta. Yogyakarta

[6] Suharyani, F. K. dan Karno. 2012. Pengaruh Metode Perbaikan Tanah Salin terhadap Serapan Nitrogen dan Fosfor
Rumput Benggala (Panicum maximum). Animal Agriculture Journal 2: 168 -176.

[7] Younesi, O., A. Baghbani, dan A. Namdari. (2013). The Effects of Pseudomonas fluorescence and Rhizobium meliloti Co-Inoculation in Nodulation and Mineral Nutrient Contents in Alfalfa (Medicago Sativa) Under Salinity Stress. Intl J Agri Crop Sci. 5 (14): 1500-1507.

[8] Cicek N, Cakirlar H (2002). The Effect of Salinity on Some Physiological Parameters in Two Maize Cultivars. Bulg. J. Plant Physiol. 28(1-2): 66-74

[9] Soepardi, G. 1983. Sifat dan Ciri Tanah. Fakultas Pertanian. Skripsi. Institut Pertanian Bogor. Bogor.

[10] Irdiana, I., Y. Sugito dan A. Soegianto. 2002. Pengaruh Dosis Pupuk Organik Cair dan Dosis Urea terhadap Pertumbuhan dan Hasil Tanaman Jagung Manis (Zea mays). J. Agrivita. 24 (1). 916.

[11] Kloepper JW. 2004. Induced Systemic Resistance and Promotion of Plant Growth By Bacillus Species. Phytopathology 94, 1259-1266.

[12] Egamberdiyeva, D. 2007. The Effect of PGPR on Growth and Nutrient Uptake of Maize in Two Different Soils. Applied Soil Ecology. Vol.36(1). P : 184-189.

[13] Patel D, CK Jha, N Tank and M. Meenu Saraf. 2012. Growth Enhancement of Chickpea in Saline Soils Using Plant Growth-Promoting Rhizobacteria. Journal of Plant Growth Regulator 31(1), 53-62. 